\title{
Research on the Influence of Perceiving Other Customer Support on Customer Citizenship Behavior
}

\author{
Hui Zhang ${ }^{1,2}$ a , Hongshen Liü, ${ }^{3, b}$, Chuang Yang ${ }^{3, \mathrm{c}}$ and Yongping Chen ${ }^{4, \mathrm{~d}^{*}}$ \\ 1School of Economics and Management, Hubei Engineering University, Xiaogan, Hube, 432100, \\ China \\ 2Research Center of Hubei Micro \& small Enterprises' Development, Hubei Engineering University, \\ Xiaogan, Hubei, 432100, China \\ 3School of Economics and Management, Changsha University of Science \& Technology, Changsha, \\ Hunan, 410000, China
}

\author{
4School of Politics and Law, Hubei Engineering University, 432100, China \\ azhang_if@126.com, bfloodwaterliu@126.com,c947701020@qq.com, d285131175@qq.com
}

Keywords: Perceiving other customer support; Customer commitment; Customer citizenship behavior

\begin{abstract}
Customer citizenship behavior has a very good promotion effect on the enterprise operation. However, the past researches paid little attention to the influence of other customers. From the consumption scenario, the support of other customers will be closer to the actual consumer and increases the validity of the conclusions of the study. This study attempts to use customer commitment as an intermediary variable to explore the impact of perceiving the support of other customers on customer citizenship behavior. Through questionnaire surveys of clothing store customers, it is considered that perceiving other customer support has a significant positive impact on customer citizenship behavior and customer commitment plays an intermediary role.
\end{abstract}

\section{Introduction}

At present, a series of common business behaviors, such as the praise and forwarding of friends circle, Taobao shop's "giving high praise and returning cash" activities, etc., are all aimed at stimulating customer citizenship behavior[1]. we should mobilize the enthusiasm of customers, so that customers can become corporate propaganda weapons and off-staff workers, this will effectively promote the enterprise practice. Related researches are also concerned about this phenomenon, that the interaction among customers will directly affect the customer service evaluation[2]. Some studies on online forums also believe that customer interaction can have an impact on customer citizenship behavior[3]. However, in current researches, the academic community paid more attention to the influence of customer perception on customer citizenship behavior, and paid less attention on perceiving the relationship between other customer support and customer citizenship, but did not pay attention to the psychological mechanism between the two. However, from the point of view of consumption, the services of other customers will be more common, and customer behavior will be deeply influenced by other customers[4]. This paper attempts to explore the relationship among perceiving other customer support, customer commitment and customer citizenship behavior. The paper also makes a survey on the relevant hypotheses through the questionnaire survey. The relevant conclusions enrich the existing theoretical viewpoints and provide relevant reference suggestions for the enterprise practice.

\section{Theoretical Review}

Customer Citizenship Behavior. Customer citizenship behavior is a kind of behavior which is beneficial to the enterprise, such as a customer's spontaneous and voluntary recommendation to other customers, helping other customers and providing opinions and suggestions to the enterprise[5]. In the process of business dealings, customers produce trading behaviors, and 
sometimes they also produce some non-trading behaviors. When customers show their satisfaction with the enterprise, they can influence other consumers through a variety of behaviors. This is what we called customer citizenship behavior. For example, they will take the initiative to promote corporate products, create new proposals for the enterprise, and provide assistance to other customers. Even when they encounter problems, they will not blame the enterprise, but show their understanding of the enterprise. These behaviors are conducive to the enterprise in the competitive advantage. Compared with the transaction behavior, customer citizenship behavior is more conducive to the enterprise operations, and the cost of enterprise is low, therefore, for enterprises, customer citizenship behavior is significant. This research focuses on how customers perceive other customers' support and when they are more possible to produce customer citizenship behavior.

Customer Commitment. American scholar Becker (1960) is the first person to formally study "commitment" as an academic concept. Customer commitment refers to a kind of psychological contract formed between the customer and a certain product or brand in the process of consuming [6]. With the deepening research of commitment, the relevant research gradually subdivides the dimension of customer commitment and divides it into two different dimensions. One is the emotional commitment, that is the reliance on the enterprise or brand from the perceptual feeling through the recognition of the enterprise's products, services, and culture. The other is the sustained commitment, that is the comparative understanding of the cost of revenue generated by the conversion of the brand. Generally speaking, customer commitment is the fundamental psychological bond that enterprises maintain their customers. Customers are generally considered to be committed to bring brand loyalty to the enterprise, repeated purchases and other positive effects [7].

Perceiving Other Customer Support. Many of the early service marketing documents regard customers as a whole. The service output mode first divides the customers in the service environment into two categories: the central customers and the other customers, and points out that there may be interaction and mutual influence between the two types of customers[8]. Other customers not only affect the service experience of the center customers, but also affect the evaluation of service organizations by the center customers[9]. The characteristics of other customers can be divided into two aspects.

One is the similarity or heterogeneity of other customers. The incompatibility between customers is usually caused by the heterogeneity between customers. The heterogeneity mainly comes from the preferences and goals of customers, the interests pursued, the stereotypes, the experiences of consumption, the differences of personality and attitudes[10]. Through customer compatibility management, homogeneous customers can be attracted to the service site to increase opportunities for positive customer interaction, thus improving customer satisfaction. Other studies have also found that the wearing of other customers can also affect customers in the same service situation, that is, when the customer is neat and tidy, other customers can get a better service experience[11]. The other is the appropriateness of the behavior of other customers. When the behavior of other customers is friendly and standard, the customer will be satisfied, otherwise the customer will feel dissatisfied [12].

\section{Research Hypotheses}

The Relationship Between Perceiving Other Customer Support and Customer Citizenship Behavior. According to the theory of interpersonal attraction, under the same service situation, "other customers" contribute to promoting the positive interaction and the quality of interaction among customers due to the characteristics such as similarity, appropriate behavior and attractive appearance[4]. When the customer is in the process of receiving service, the behavior of other customers is also an important factor that affects the decision of the customer besides the influence of the clerk. Interpersonal attraction theory holds that people's positive behaviors (such as helping, settling conflicts, suggestions and other appropriate behaviors) and the expression of verbal feelings (such as recognition, respect and gratitude) are treated as rewarding behaviors that can lead to reciprocity. While other customer behaviors may have appropriate contextual differences, the 
behaviors of other customers which delight customers are generally friendly and socially compliant. Therefore, we put forward the hypothesis 1.

H1: Perceiving other customer support has a positive impact on customer citizenship behavior.

The Relationship Between Perceiving Other Customer Support and Customer Commitment. Many customers regard the service engagement process as a social activity. In order to promote social interests, it is better to play the role of non-staff "supervisor", and customers are more likely to interact with "other customers" during service participation[14]. When feeling the support of "other customers", the customer's social needs are satisfied. The process and results are more objectively understood by them, so customers are more likely to be satisfied with the service experience. This will strengthen the linkages between customers and enterprises and enhance the level of customer commitment. Therefore, we propose Hypothesis 2.

$\mathrm{H} 2$ : Perceiving other customer support has a positive impact on customer commitment.

The Impact of Customer Commitment on Customer Citizenship Behavior. Customer citizenship behavior is a kind of behavior that is out of the role. It is in the absence of customer interest in the case, and the customers take the initiative to make business-friendly behaviors. When customers have a stronger psychological connection to their enterprises and their senses of belonging are constantly improving, customers are more likely to produce citizenship behavior. At the same time, customer's satisfaction with services can have a positive impact on customer citizenship $[15,16]$. From the perspective of customer commitment, the satisfaction of the service comes from the customer's solution. When the customer's commitment level is high, the customer is also more willing to evaluate the service level from the perspective of goodwill. Therefore, we put forward the hypothesis 3:

H3: Customer commitment has a positive impact on customer citizenship behavior.

The Impact of Customer Commitment on Perceiving Other Customer Support and Customer Citizenship Behavior. When customer commitment is promoted, customer satisfaction can be strengthened. At that time, customers can easily show citizenship behaviors for salesmen and other customers. At the same time, customers will attribute their behavior to other customers' friendly cooperation and assistant's help. The perception of other customers' support will have a positive impact on the customer's emotional identity, and then promote the occurrence of citizenship behavior. During the travel process, customer interaction support has a significant positive impact on customer's word of mouth, and the mechanism is decided by the[17] customer commitment. Customer commitment not only helps customers get a certain degree of psychological benefits, but also enables them to feel social support during their participation in the service process. As a result, customers are more likely to conduct customer citizenship behavior in the form of word of mouth communication. According to social exchange theory[18], customers will generate resources and feelings of exchange with enterprises and other customers, get the support of other customers, and show customer citizenship behavior to support enterprises and other customers. Therefore, we put forward the hypothesis 4 .

H4: Customer commitment has a mediating effect between perceiving other customer support and customer citizenship behavior

\section{Research Design}

This study uses a questionnaire research method, and reviews many mature scales which have been published at home and abroad. Among them, perceiving other customer support, customer commitment and customer citizenship behavior are respectively adopted by Moore's (2005), Groth's(2001) and Fan Jun's (2011) scale contents, which are combined with the clothing store situation of the survey. The questionnaire was conducted in the form of a seven-point scale, ranging from 1 to 7 with strongly disagree to strongly agree. Perceiving other customer support uses "other customers' fitting effect can attract my attention", "other customers will take the initiative to give me advice" and other four questions. Customer commitment uses "I am very concerned about the operation of this clothing store's situation", "If this store collapses, it is a huge loss to me" and other three questions. Customer citizenship behavior uses "If other customers have any problems, I will 
take the initiative to ask", "I will recommend this shop to the people around me" and other four questions. Sample distribution was mainly concentrated in Wuhan City of Hubei Province, Changsha City of Hunan Province. A total of 305 questionnaires were distributed, and 260 valid questionnaires were collected. The effectiveness of the questionnaires was about $86.6 \%$. Among them, women accounted for $67.8 \%$, men accounted for $32.2 \%$. The span of age changes from 17 to 42 years old.

Statistics Description. By using SPSS software, we put variables: perceiving other customer support, customer commitment and customer citizenship behavior in an exploratory factor analysis, with the purpose of testing unrotated factors and analyzing the results. The result shows that the explanation rate of the first public factor is only $11.08 \%$, and more factors are precipitated. Other customer support and customer civic behavior are not homologous, the study was not affected by the deviation of the common method. Related analysis results are shown in Table 1. Among them, other customer support is positively related to customer commitment and customer citizenship behavior. Customer commitment is positively correlated with customer citizenship behavior.

Table 1 Correlation coefficient between variables $(\mathrm{N}=150)$

\begin{tabular}{cccc}
\hline Variables & $\begin{array}{c}\text { Other customer } \\
\text { support }\end{array}$ & $\begin{array}{c}\text { Customer } \\
\text { commitment }\end{array}$ & $\begin{array}{c}\text { Customer } \\
\text { citizenship } \\
\text { behavior }\end{array}$ \\
\hline $\begin{array}{c}\text { Other customer } \\
\text { support }\end{array}$ & 1 & - & - \\
$\begin{array}{c}\text { Customer } \\
\text { commitment } \\
\text { Customer } \\
\text { citizenship } \\
\text { behavior }\end{array}$ & $0.185^{* *}$ & 1 & - \\
\hline
\end{tabular}

Note: * Significantly at $\mathrm{P}<0.05$ level; $* *$ Significantly at $\mathrm{P}<0.01$ level.

Hypothesis Test. Based on the relevant research and the analysis of the relationship between the variables and the above assumptions, we constructed the structural equation mode. The maximum likelihood method was used to fit the mode. The fitting indexes were good ( $\chi 2$ / df $=2.56$, RMSEA $=0.07, \mathrm{GFI}=0.89, \mathrm{NNFI}=0.88, \mathrm{NFI}=0.91, \mathrm{CFI}=0.94)$. The relational mode is acceptable.

We use the Bootstrap program in the AMOS software to test the significance of the mediation effect [19]. A total of 2000 Bootstrap samples were randomly extracted from the original data, and the data was fitted by the mode. We saved the path coefficients of each path after running 2000s and calculated the average path coefficient of the mediation effect. The results showed that the intermediary effect from other customer support to customer citizenship behavior was $95 \%$, the level of confidence interval was [0.028,0.309], and the interval did not contain 0 , so the mediating effect was significant. The direct effect of other customer support to customer citizenship behavior was 0.18 , and the mediating effect of customer commitment was 0.17 . The total effect is the sum of the direct effect and the total mediation effect, which is 0.35 , and the effect of the mediation effect is $49.5 \%$. Other customer support directly affects customer citizenship behavior and supports the assumptions through customer commitment that indirectly affects customer citizenship behavior.

\section{Analysis Conclusions}

By discussing the relationship between perceiving other customer support, customer commitment and customer citizenship behavior, this paper argues that, firstly, perceiving other customer support has a positive impact on customer citizenship behavior. In the course of consumers receiving service, perceiving the supporting behavior of other customers will promote customer citizenship behavior. Secondly, perceiving other customer support has a positive impact on customer commitment. Perceiving other customer support can enhance customer satisfaction with the service, 
and enhance the psychological link between customer and enterprise or brand. If customers agree with corporate behavior, customer commitment levels will be improved. Thirdly, customer commitment has a positive impact on customer citizenship behavior. When the psychological bond between customer and enterprise is stronger, the more likely it is for customers to be satisfied with the service and the more likely it is for customers to produce customer citizenship behavior. Fourthly, customer commitment plays an intermediary role in the relationship between the perceiving other customer support and customer citizenship behavior. Perceiving other customer support affects the relationship between the customer and the business and strengthens the customer's approval of the business or brand so that the customer tends to provide favorable behavior to the enterprise or other customers.

From the business point of view, firstly we should pay attention to the occurrence of customer citizenship behavior, and provide customer citizenship support as far as possible. Such as giving customers more opportunities to participate in the service process, appropriate authorization to encourage employees to improve customer support levels, so that customers have more opportunities to serve other people. Secondly, we should pay attention to the customer relationship in the service scenario, and customers will be affected by the presence of other customers. On the one hand, we should control the scene, and block the negative news or atmosphere. On the other hand, we should divide the customers into different groups, and arrange compatible customers to participate together to reduce the occurrence of discord. Thirdly, we must pay attention to the level of customer commitment. Customer commitment is different from customer satisfaction, customer loyalty and other concepts, the most important point is that customer commitment is the psychological bond with the enterprise or brand. It is the customer's identity of the company's products, services or culture that has a stronger predictive value for customer behavior. In the interaction between enterprises and customers, enterprises must educate their customers through the corporate elements of brands, products and services, so as to ensure that customers and enterprises are consistent in the sense of value so as to win the psychological share of the market.

Due to factors such as research convenience and other factors, the samples of this study mainly come from the customers of the apparel industry shops in Wuhan City of Hubei Province and Changsha City of Hunan Province. The sample size and the research industry have obvious limitations. The external validity of the research conclusion needs to be improved. In the future, we need to further utilize other industries such as hair salons, travel agencies, supermarkets and hotels for research and verification.

At the same time, this article only considers two variables: perceiving other customer support and customer commitment, and explores their impact on customer citizenship behavior. Due to the development of the service industry and the change of marketing research service paradigm, customer citizenship behavior will become the key for enterprises to gain competitive advantage. We need to introduce other variables such as organizational socialization, customer satisfaction, customer education and so on, to deeply discuss the psychological mechanism of customer citizenship behavior so as to expand the research field and enhance the operational value of enterprise practice.

\section{Acknowledgements}

Fund support: National Natural Science Fund(71672053); The Research Project of Provincial Teaching Reform of Universities in Hubei(2015400); Planning Fund Project of the Ministry of Education(15YJA840007)

\section{References}

[1] K.S.Liu: How to look at the events in WeChat Moments that friends help to vote, help to support and help to transmit? Available: https://www.zhihu.com/question/30910543(2016).(In Chinese)

[2] X.C.Fan and J.Z.Li: An Empirical Study of Customer Restaurant Experience, Tourism Tribune, 
vol. 21, pp. 56-61, 2006.(In Chinese)

[3] Y.P.Chang, Z.Y.Lu and D.H.Zhu: The Research on the Impact of Online Social Support on Customer Citizenship Behavior - based on the Empirical Analysis of the Brand Community, Chinese Journal of Management, vol. 12, pp. 1536-1543, 2015.

[4] J.X.Li, W.Liu, H.S.Liu and H.He: How do "Other Customers in the Shared Service" Promote the Customer's Service Experience? An Empirical Study Based on the Theory of Interpersonal Attraction, Marketing, vol. 11, pp. 46-58, 2015.(In Chinese)

[5] L.L.Guo and M.Z.Lin: A Review of the Research on Customer Citizenship Behavior and Its Management Enlightenment, Human Resources Development of China, p. 41-48, 2015.(In Chinese)

[6] G. Fullerton, "The service quality-loyalty relationship in retail services: does commitment matter?," Journal of Retailing \& Consumer Services, vol. 12, pp. 99-111, 2005.

[7] N.J.Sun and G.Q.Guo: Customer Commitment, Self Promotion and Customer Citizenship Behavior: the Driving Mechanism and Regulation Effect from the Perspective of Social Exchange Theory, Business Review, vol. 28, pp. 187-197, 2016.

[8] Langeard and Éric, "Services marketing: New insights from consumers and managers," Marketing Science Institute, 1981.

[9] R. Nicholls, "New directions for customer - to - customer interaction research," Journal of Services Marketing, vol. 24, pp. 87-97, 2010.

[10] C. L. Martin, "Retrospective: compatibility management: customer-to-customer relationships in service environments," Journal of Services Marketing, vol. 3, pp. 5-15, 2016.

[11]S. Uhrich and M. Benkenstein, "Physical and social atmospheric effects in hedonic service consumption: customers' roles at sporting events," Service Industries Journal, vol. 32, pp. 1741-1757, 2012.

[12]E. Di, C. J. Huang, I. Chen, and T. C. Yu, "Organisational justice and customer citizenship behaviour of retail industries," Service Industries Journal, vol. 30, pp. 1919-1934, 2010.

[13] C. Ellegaard, "Interpersonal attraction in buyer-supplier relationships: A cyclical model rooted in social psychology," Industrial Marketing Management, vol. 41, pp. 1219-1227, 2012.

[14] K. Harris and S. Baron, "Consumer-to-Consumer Conversations in Service Settings," Journal of Service Research, vol. 6, pp. 287-303, 2004.

[15]L.S.Xie, W.G.Shen and X.D.Liang: A Study on the Relationship between Customer Perceived Service Fairness and Customer Citizenship Behavior -- An Empirical Study Based on the Network Service Environment, Business Review, vol. 20, pp. 17-24, 2008.

[16] M. Groth, Managing service delivery on the internet: facilitating customers' coproduction and citizenship behaviors in service organizations: The University of Arizona, 2001.

[17] M. Fakharyan, S. Omidvar, M. R. Khodadadian, M. R. Jalilvand, and L. N. Vosta, "Examining the effect of customer-to-customer interactions on satisfaction, loyalty, and word-of-mouth behaviors in the hospitality industry: the mediating role of personal interaction quality and service atmospherics," Journal of Travel \& Tourism Marketing, vol. 31, pp. 610-626, 2014.

[18] R. Cropanzano and M. S. Mitchell, "Social Exchange Theory: An Interdisciplinary Review," Journal of management, vol. 31, pp. 874-900, 2005.

[19]B. Efron, "Bootstrap Methods: Another Look at the Jackknife," vol. 7, pp. 1-26, 1979. 